\title{
Developing the Student Anchor Engagement Framework
}

\author{
Jennifer Johnson Kebea
}

\begin{abstract}
Modern urban and metropolitan universities are increasingly obliged to recognize their role as anchor institutions. These same institutions of higher education (IHEs) also have a responsibility to educate students to be responsible and participatory citizens in society. An increasing number of IHEs recognize these distinct commitments as central to the public purpose of higher education. However, few intentionally involve students in anchor mission work. This misalignment denies students a rich opportunity for civic learning and democratic engagement. Furthermore, it prevents IHEs and their surrounding communities from realizing the benefits of harmonizing these two commitments. This mixed-methods research study resulted in the development of the Student Anchor Engagement Framework, a 36-item strategic framework designed to identify how IHEs can intentionally involve students in anchor strategy. The framework derives from The Democracy Collaborative's Anchor Institution Community Benefit Dashboard. Expert participants ranked all items included in the framework as to their potential to influence student civic learning and democratic engagement. Implications of this research study include the potential for IHEs to consider, strategically, ways to align student civic learning with anchor institution practices for the advancement of both pursuits.
\end{abstract}

Keywords: anchor institution; civic learning; democratic engagement; student engagement

\section{Introduction}

Higher education in the United States aims to fulfil multiple missions. While preparing students to serve as professionals in their field of study remains the primary goal, many urban and metropolitan institutions of higher education (IHEs) also embrace two public purposes. The first is to educate students to be responsible and participatory citizens in society. The second is to consider how an IHE serves as an institutional citizen and anchor institution within the local communities where they operate. In many ways, these two public purposes of higher education are complimentary; however, researcher or practitioners do not typically consider them together.

This mixed-methods study sought to develop a strategic framework, in which IHEs, serving as anchor institutions, can facilitate civic learning and democratic engagement by involving students in the anchor mission of the institution. Second, this study aimed to ensure that said framework presented customizable and sustainable engagement strategies for diverse IHEs.

This study resulted in the development of a 36-item framework, referred to as the "Student Anchor Engagement Framework" (Kebea, 2016), which mirrors the structure of The Democracy Collaborative Anchor Institution Community Benefit Dashboard, here abbreviated as the "Anchor Dashboard." The Collaborative designed this Anchor Dashboard to help IHEs identify and measure how they are serving as an anchor institution within the community (Dubb, 
McKinley, \& Howard, 2013). The Student Anchor Engagement Framework augments the Anchor Dashboard by including student engagement in anchor strategy. The Student Anchor Engagement Framework is organized into the same five categories as the Anchor Dashboard, including: (a) anchor mission alignment; (b) economic development; (c) community building; (d) education; and (e) health, safety, and environment (Dubb, 2015). All 36 items included in the Student Anchor Engagement Framework had the best potential for positive impact upon student civic learning and democratic engagement, as judged by expert participants in this research Delphi-method study.

Aligning the Student Anchor Engagement Framework with the Anchor Dashboard was both intentional and strategic. The Anchor Dashboard was one of the first tools to define categorically how IHEs could serve as anchor institutions within their communities across a variety of systems (Dubb et al., 2013). However, the Anchor Dashboard contains very limited information on how to involve students in anchor strategy. Therefore, the Student Anchor Engagement Framework attempts to build upon and complement the Anchor Dashboard, while providing vast accessibility and utility for IHEs considering strategies to involve students in institutional anchor strategy for enhancing students' overall civic development. The Student Anchor Engagement Framework, in alignment with the Anchor Dashboard (Dubb et al., 2013), builds upon and expands research exploring student involvement in anchor strategy by Wittman and Crews (2012), as well as Guinan, McKinley, and Yi (2013).

This article will describe the process of developing the Student Anchor Engagement Framework (Kebea, 2016) and explore the significance of this framework within the field of higher education. This research is significant to a national audience because it provides a roadmap for IHEs to engage, strategically and intentionally, their students in the anchor work of their institutions. This ultimately creates a broader network of IHEs to invest jointly in the interrelated concepts of anchor strategy, civic learning, and democratic engagement.

\section{Literature Review}

The literature that informed this research stemmed from three concepts: the role of IHEs to serve as anchor institutions within their local communities, the role of IHEs to act as civic educators of students by embracing the tenets of civic learning, and the importance of recognizing the foundational role that democratic engagement plays in both commitments. The connection between IHEs' dual roles as both civic educator and anchor institution are not readily apparent within literature or practice. However, the opportunity for explicit connection of these concepts does exist and stands greatly to inform the practice of each individual commitment.

\section{Anchor Institutions}

Anchor institutions are place-based organizations, including IHEs and health systems, which link closely to their local communities because of both organizational goals and capital investments (Dubb et al., 2013). The historical origins of anchor institutions goes back to 1862 with the passage of the first Morrill Act. This legislation reserved land for 69 state-supported IHEs, which now number more than 100 nation-wide and are officially known as land-grant institutions (Renaud, 2008). As part of the land-grant process, IHEs took on the responsibility of producing 
research and knowledge applicable to both agriculture and industry in largely rural communities (Alperovitz \& Howard, 2005). Today, many of these IHEs continued to focus energy and effort on institutional engagement with their local communities, thus paving the way for today's modern concept of a higher education anchor institution (Cantor, 2009).

More recently, a growing number of IHEs have worked to redefine their relationships with and responsibilities to the communities where they reside. Embracing an anchor mission has materialized individually for unique IHEs and many urban and metropolitan universities have now focused resources on problem solving efforts relevant to their specific communities. Furthermore, IHEs are discovering that they can align institutional will and resources to the benefit of both the community and the IHE. Anchor Dashboard is a key piece of research advancing this work. It identifies five categories and twelve outcomes related to IHEs and their roles as anchor institutions (Dubb et al., 2013). The outcomes identified within these categories provide a roadmap for present day urban and metropolitan IHEs to consider how they currently serve as an anchor institution and how they might consider expanding their commitment to the role.

\section{Civic Learning}

Civic learning references the "knowledge, skills, values, and the capacity to work with others on civic and societal challenges" (AAC\&U, 2012, p. 4). IHEs have largely embraced their roles as purveyors of civic learning, dating back as far as the early 1600s and the founding of Harvard University, the first IHE in the nation (Jacoby, 2009). This commitment would continue through the nineteenth century and into the twentieth century; John Dewey proclaimed that formal education should play a key role in democracy by teaching students to be civically engaged members of society (Jacoby, 2009).

By the twenty-first century, IHEs were re-examining their role in civic learning. In 2012, the National Task Force on Civic Learning and Democratic Engagement released a comprehensive report entitled A Crucible Moment: College Learning \& Democracy's Future. This report sought to remind IHEs about their role as civic educators and their responsibility to ensure that their graduates leave prepared to be knowledgeable, responsible, and participatory citizens (AAC\&U, 2012). While IHEs have often fallen short in this pursuit, many have nevertheless remained committed. Nearly 1,100 IHEs hold membership with Campus Compact (2016), and 361 IHEs currently hold the Carnegie Foundation's elective community engagement classification (Saltmarsh \& Driscoll, 2015).

\section{Democratic Engagement}

The final theme explored in this literature review is democratic engagement. Democratic engagement is identified by "deep engagement with the values of liberty, equality, individual worth, open mindedness, and the willingness to collaborate with people of differing views and backgrounds towards common solutions for the public good" (AAC\&U, 2012, p. 3). Like civic learning, democratic engagement is not a nascent concept in American higher education. In fact, founding fathers Benjamin Franklin and Thomas Jefferson were both early advocates of the democratic purposes of higher education (Boyte \& Kari, 2000; Harkavy \& Hartley, 2008). By 
the turn of the twentieth century, John Dewey would also be clamoring for schools to be models of democracy (Dewey, 1900).

The concept of democratic engagement ultimately serves as a bridge between the role of IHEs to serve as both civic educators and anchor institutions, illuminating a path and rationale for student involvement in anchor strategy. While research or practice have not traditionally connected these concepts, precursors are present in the literature. For example, Saltmarsh, Hartley, and Clayton (2009) begin to describe these linked concepts by stating:

Democratic engagement locates the university within an ecosystem of knowledge production. In this ecosystem, the university interacts with outside knowledge producers in order to create new problem-solving knowledge through a multi-directional flow of knowledge and expertise. In this paradigm, students learn cooperative and creative problem solving within learning environments in which faculty, students, and individuals from the community work and deliberate together. (p.11)

IHEs that utilize their knowledge and expertise to solve complex public problems while engaging in authentic collaboration with community are modeling democratic engagement. This orientation readily lends itself to conceptualizing how students can play an active role in anchorinstitution strategy.

\section{Methodology}

This mixed-methods study utilized an explanatory sequential design, analyzing quantitative data collected during phase one of the study to inform the second qualitative phase (Creswell, 2012). During phase one, the author utilized a three-round Delphi study featuring a panel of 25 national higher education experts. Two focus groups provided feedback during phase two. The focus groups totaled nine engaged students at Drexel University, a large, private, urban, research institution located in Philadelphia, PA. Drexel's Institutional Review Board (IRB) granted approval in advance of this research study.

\section{Delphi Method}

The Delphi method served as a flexible mixed-methods research tool during the first phase of this study. This research protocol engages an expert panel to provide responses and rankings to a structured series of questions or statements over several iterative phases (Skulmoski, Hartman, \& Krahn, 2007). Many industries use it, including higher education, to assist with both decisionmaking and consensus building (Linstone \& Turoff, 1975).

The author selected the Delphi method because of its complementarity to this study. The Delphi method provides a well-structured process for organizing and ranking new information collected about a topic (Skulmoski et al., 2007). It also provides a democratic way to gather information, which was particularly relevant given the nature and context of this research study. Day and Bobeva (2005) explain that "whatever the perceived reason for its choice, the method offers reliability and generalizability of outcomes, ensured through iteration of rounds for data collection and analysis, guided by the principle of democratic participation and anonymity" (p. 104). Further, each expert participant's opinions and contributions carry equal weight during 
both data collection and analysis (Dalkey, 1972).

The author identified expert participants for this Delphi study nationally through consultation with several professional organization including the Coalition of Urban and Metropolitan Universities, the International Association of Research on Service Learning and Community Engagement, the Anchor Institution Task Force, and The Democracy Collaborative. Participant eligibility was confirmed utilizing criteria including: (a) three or more years of experience in the field of higher education as related to civic learning and/or anchor institution research; (b) two or more publications in an associated field; (c) affiliations with one of the professional organizations listed above; and (d) the willingness and time to participate in the study. Participants needed to meet two of the first three criteria, and all needed to meet the final criterion in order to be part of the study.

Demographics collected on the group indicate that diverse in gender and age. The majority of participants (23) identified as white/Caucasian. One participant identified as Black or African American, and one identified as Native American or American Indian. Professional roles of participants included engagement center directors and staff, service-learning facilitators, student leadership facilitators, anchor strategy implementers, engaged faculty, senior-level higher education administrators, and representatives from organizations affiliated with anchor strategy and/or civic learning. Fourteen expert participants hold doctoral degrees, nine hold master's degrees, and two hold bachelor's degrees in their respective fields.

Participants, upon request, described the profile of their current institutional home. The majority of institutions in this study were large, urban research institutions. There were both public (12) and private (9) institutions represented. A smaller number of suburban (3) and rural (4) institutions were also represented in the sample.

The survey instrument utilized in this Delphi study included a series of three online surveys administered via email using the survey tool Qualtrics. The first round of the Delphi study was qualitative and consisted of a series of open-ended questions aimed to identify potential ways that students could be involved in anchor strategy. The second and third rounds utilized 4-point Likert-type scales to ask expert participants to review responses collected during round one and rank both the quality of the proposed item to have a positive impact on student civic learning and democratic engagement, and the overall ease of its implementation. In order for an item to be included in the final emergent framework, three distinct measurements were essential. First, the item needed to have a mean score of 2.0 or less, indicating that the expert participants had judged it to have a positive impact on student civic learning and democratic engagement. Second, we calculated two metrics that indicate consensus. The first was the interquartile range (IQR), which calculates the absolute value of the difference between the $75^{\text {th }}$ and $25^{\text {th }}$ percentiles (Rayens $\&$ Hahn, 2000), with values of 1.0 indicating a high level of consensus (Von der Gracht, 2012). Finally, $80 \%$ of expert participants had to rank the Likert item as a 2.0 or less for inclusion on the final framework. If items did not meet all three of these criteria, the authors ejected those items from the final framework. After analysis was complete, 36 unique items remained in the framework across five categories. The author organized items within categories based on the implementation levels easy, moderate, or difficult, calculating these levels based on additional Likert scale data collected during round two and three of the survey. 
Ultimately, 19 of the 25 total participants completed all three rounds of the Delphi study. This represents a $66 \%$ final retention rate, with retention rates between rounds registering at $88 \%$ and $86 \%$ respectively. These retention rates fall within acceptable rate guidelines as suggested by Sumison (1998).

\section{Focus Groups}

The second phase of data collection during this research study included two focus groups. The researcher utilized a purposeful sampling technique to identify students to participant in the focus groups. The focus groups were comprised of engaged students from Drexel University, a large, private, urban, research institution that has largely embraced its identity as an anchor institution in Philadelphia, PA. The author recruited students specifically for their participation in programming offered through Drexel's Lindy Center for Civic Engagement and their individual ability to contribute to a review and conversation of the Student Anchor Engagement Framework, as perceived by the researcher.

Each focus group had to review the emergent framework and providing feedback. Key questions that the author asked during the focus groups revolved around the clarity of the framework, prior involvement of the participants in the activities listed in the framework, and their perceived opportunity for new learning through involvement in the listed activities. Each focus group was audio recorded and transcribed. Data was hand-coded and analyzed using a priori codes that mirrored questions asked during the focus groups.

Integrating feedback from the focus groups allowed the early framework to be further customized for usage at Drexel University. This opportunity to customize the framework is an important step towards ensuring that IHEs can implement an anchor strategy with student engagement within the contexts and realities of their diverse institution.

\section{Results}

The Delphi study resulted in the development of a 36-item strategic framework titled the Student Anchor Engagement Framework, shown in Figure 1. The framework identifies key ways that students can be involved in anchor strategy, along with their perceived ease of implementation (Kebea, 2016). All engagement items included in the framework ranked as having a potential positive impact on student civic learning and democratic engagement.

The framework shown in Figure 1 is the generic template developed through the Delphi method in phase one of this research study. Phase two, which utilized focus group feedback from students at Drexel University, resulted in a slight variation to the generic framework with the addition of one item to the list. IHEs interested in utilizing the Student Anchor Engagement Framework should consider hosting student focus-group sessions to personalize further the framework to the realities and opportunities available on their own campuses. 


\begin{tabular}{|c|c|c|}
\hline & Student Involvement in Anchor Strategy & Implementation \\
\hline \multirow{12}{*}{ 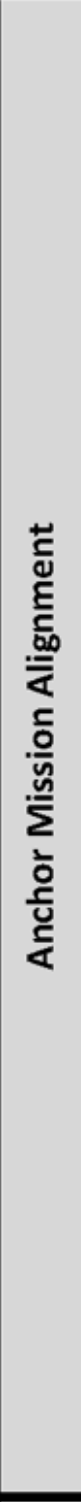 } & $\begin{array}{l}\text { Include students on university committees that develop plans for } \\
\text { the institution's anchor strategy (e.g. Anchor Institution } \\
\text { Committee) }\end{array}$ & Easy \\
\hline & $\begin{array}{l}\text { Involve the Student Government Association in anchor institution } \\
\text { strategy and planning }\end{array}$ & Easy \\
\hline & $\begin{array}{l}\text { Offer courses that educate students about the anchor strategies of } \\
\text { the university }\end{array}$ & Easy \\
\hline & $\begin{array}{l}\text { Align service-learning coursework with key anchor institution } \\
\text { strategies }\end{array}$ & Moderate \\
\hline & $\begin{array}{l}\text { Involve students in the strategic planning process of the institution } \\
\text { (e.g. mission statement revisions or update of strategic plan) }\end{array}$ & Moderate \\
\hline & $\begin{array}{l}\text { Encourage student organizations to become knowledgeable about } \\
\text { the university's role as an anchor institution }\end{array}$ & Moderate \\
\hline & $\begin{array}{l}\text { Provide internship/co-op opportunities for students to work closely } \\
\text { with university administration who are charged with implementing } \\
\text { anchor strategy }\end{array}$ & Moderate \\
\hline & $\begin{array}{l}\text { Instill in students a sense that they are part of the broader } \\
\text { community outside of the university }\end{array}$ & Moderate \\
\hline & $\begin{array}{l}\text { Involve students in community-engaged research aimed at } \\
\text { examining facets of anchor institution work (e.g. community-asset } \\
\text { mapping) }\end{array}$ & Moderate \\
\hline & $\begin{array}{l}\text { Involve students in the evaluation of the university's achievement } \\
\text { of anchor institution goals }\end{array}$ & Moderate \\
\hline & $\begin{array}{l}\text { Encourage student activism that might lead to better university } \\
\text { anchor practices (e.g. students advocating for the university to } \\
\text { procure goods locally or to divest endowment funding from } \\
\text { carbon, etc.) }\end{array}$ & Moderate \\
\hline & $\begin{array}{l}\text { Give students responsibility for implementing part of the anchor } \\
\text { strategy }\end{array}$ & Moderate \\
\hline \multirow{5}{*}{ 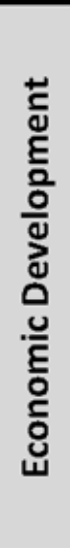 } & $\begin{array}{l}\text { Students provide tax prep services through a service-learning } \\
\text { course }\end{array}$ & Easy \\
\hline & $\begin{array}{l}\text { Educate students about local issues of gentrification influenced by } \\
\text { the student apartment and home rental market }\end{array}$ & Moderate \\
\hline & $\begin{array}{l}\text { Students provide financial education workshops to the community } \\
\text { through a service-learning course }\end{array}$ & Moderate \\
\hline & Students intern with minority-owned businesses in the community & Moderate \\
\hline & $\begin{array}{l}\text { Students provide technical business support to local businesses } \\
\text { through service-learning courses (e.g. business plan creation, social } \\
\text { media marketing strategy, etc.) }\end{array}$ & Moderate \\
\hline
\end{tabular}




\begin{tabular}{|c|c|c|}
\hline & $\begin{array}{l}\text { Involve students in research projects around local economic } \\
\text { development topics connected to an anchor mission (e.g. student } \\
\text { local spending, local hiring trends at the University, etc.) }\end{array}$ & Moderate \\
\hline & $\begin{array}{l}\text { Students partner with community members to launch small } \\
\text { businesses in the community }\end{array}$ & Difficult \\
\hline \multirow{6}{*}{ 을 } & $\begin{array}{l}\text { College students bring enrichment activities into local K-12 schools } \\
\text { through service-learning courses (e.g. arts, music, or STEM) }\end{array}$ & Easy \\
\hline & $\begin{array}{l}\text { College students tutor or mentor K-12 students in local after school } \\
\text { programs }\end{array}$ & Moderate \\
\hline & $\begin{array}{l}\text { College students provide college access support to local high school } \\
\text { students (e.g. completing applications, FAFSA, writing essays, etc.) }\end{array}$ & Moderate \\
\hline & College students serve as ESL tutors in K-12 schools & Moderate \\
\hline & $\begin{array}{l}\text { College students provide support around literacy in K-12 schools } \\
\text { (e.g. America Reads) }\end{array}$ & Moderate \\
\hline & $\begin{array}{l}\text { College students utilize Federal Work Study dollars to fund } \\
\text { internships in K-12 schools }\end{array}$ & Moderate \\
\hline \multirow{6}{*}{ 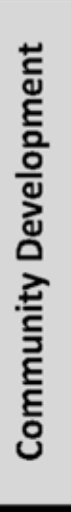 } & Students intern with local community development centers & Easy \\
\hline & $\begin{array}{l}\text { Students provide support to local community-based business } \\
\text { centers }\end{array}$ & Moderate \\
\hline & $\begin{array}{l}\text { Students provide technical assistance or capacity-building services } \\
\text { to nonprofits through a service-learning course }\end{array}$ & Moderate \\
\hline & $\begin{array}{l}\text { Involve students in a research project examining capacity of local } \\
\text { nonprofits }\end{array}$ & Moderate \\
\hline & $\begin{array}{l}\text { Involve students in a research project examining the community } \\
\text { civic health index }\end{array}$ & Moderate \\
\hline & Students serve on local community advisory boards & Moderate \\
\hline \multirow{5}{*}{ 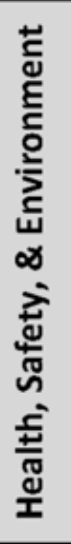 } & $\begin{array}{l}\text { Involve nursing and health professions students in service-learning } \\
\text { courses connected to community clinics }\end{array}$ & Easy \\
\hline & $\begin{array}{l}\text { Law students provide pro-bono legal services to local community } \\
\text { members }\end{array}$ & Moderate \\
\hline & $\begin{array}{l}\text { Students participate in community-engaged research projects } \\
\text { examining key community health indicators (e.g. lead paint, } \\
\text { asthma triggers, etc.) }\end{array}$ & Moderate \\
\hline & $\begin{array}{l}\text { Students help local community residents connect to public benefits } \\
\text { such as healthcare }\end{array}$ & Moderate \\
\hline & $\begin{array}{l}\text { Involve engineering or environmental science students in projects } \\
\text { focused on air quality, surface groundwater, etc. }\end{array}$ & Moderate \\
\hline
\end{tabular}

Figure 1. Student Anchor Engagement Framework (Kebea, 2016). 


\section{Conclusion}

This research study resulted in the development of the Student Anchor Engagement Framework, which identifies specific ways that students can be involved in anchor strategy (Kebea, 2016). Multiple implications of this research exist for university personnel that support community engagement and/or anchor strategy, university leadership, and students themselves.

This work has the potential to encourage IHEs to reconsider how each institution conceptualizes and organizes community engagement across internal divisions, especially those that typically do not intersect within the institution (Kebea, 2016). For example, an IHE with a traditional (perhaps even isolated) community engagement center may consider how a student-focused collaboration with the campus procurement office might advance both anchor strategy and civic learning. A natural first step might involve the community engagement center and procurement office co-sponsoring a student intern, who focuses on developing a strategy to encourage other students to spend locally. Simultaneously, the community engagement center might start to infuse information about the IHE's role as an anchor institution into student workshops and trainings, sparking further interest and involvement of students in their institution's anchor strategy. More advanced approaches might begin to involve faculty who incorporate anchor mission concepts into curriculum leveraged to advance specific aspects of anchor strategy. Connecting anchor strategy to both curricular and co-curricular student pursuits is a clear way to enhance congruency between the IHE's role as civic educator of students and as anchor institution within the community.

This research also presents implications for university leadership. As universities continue to participate in conversations around the significance of institutional investment within local communities (Campus Compact, 2016), the Student Anchor Engagement Framework will be useful to IHEs that seek ways to leverage one of their greatest resources, students, to aid in the advancement and congruence of this work. This alignment is crucial to the future success of IHE anchor strategy because initiatives and strategic directions that do not directly involve and benefit students, the core stakeholders, have a repeated tendency to diminish over time.

Furthermore, engaged IHEs that pursue national recognition including through the elective Carnegie Community Engagement Classification (Saltmarsh \& Driscoll, 2015), should continue to advocate for the addition of reporting requirements that aim to measure their commitment to serve as both civic educators to students and as anchor institutions within their local communities (Kebea, 2016). This intentional connection will allow IHEs to more cohesively understand and share their institutional commitments and accomplishments within the wide expanse of community engagement.

Finally, for current students (and the staff and faculty that support them), this research study and the resultant Student Anchor Engagement Framework provide a roadmap illuminating specific examples of how students can engage in, and potentially learn from, this important work. This framework is not exhaustive or inflexible. Instead, it serves a springboard for the creative inquiry and involvement of students in all aspects of anchor institution strategy. 


\section{References}

Alperovitz, G., \& Howard, T. (2005). The next wave: Building a university civic engagement service for the twenty-first century. Journal of Higher Education Outreach and Engagement, 10 (2), 141-157.

American Association of Colleges \& Universities (2012). A crucible moment: College learning and democracy's future. Washington, D.C.

Ashworth, K.H. (1964). Urban renewal and the university: A tool for campus expansion and neighborhood improvements. The Journal of Higher Education, 35 (9), 493- 496.

https://doi.org/10.1080/00221546.1964.11772976

Boyte, H.C., \& Kari, N.N. (2000). Renewing the democratic spirit in American colleges and universities: Higher education as public work. In T. Ehrlich (Ed.), Civic responsibility and higher education (pp. 37-60). Westport, CT: The American Council on Education and the Oryx Press.

Campus Compact. (2016). Creating a great campus civic action plan. Retrieved from http://compact.org/Campus-Compact-Action-Plan.pdf

Cantor, N. (2009). A new Morrill Act: Higher education anchors the "Remaking of America." Presidency, 12 (3), 16-22.

Creswell, J.W. (2012). Qualitative inquiry and research design: Choosing among five approaches $\left(3^{\text {rd }}\right.$ ed.) Thousand Oaks, CA: Sage Publications, Inc.

Dalkey, N.C. (1972). The Delphi method: An experimental study of group opinions. In N.C. Dalkey, D. L. Rourke, R. Lewis, \& D. Snyder (Eds.), Studies in the quality of life: Delphi and decision-making (pp. 13-54). Lexington, MA: Lexington Books.

Day, J. \& Bobeva, M. (2005). A generic toolkit for the successful management of Delphi studies. The Electronic Journal of Business Research Methodology, 3 (2), 102- 116.

Dewey, J. (1900). The school and society. Chicago, IL: The University of Chicago Press.

Dubb, S. (2015). Anchor Institution Community Benefit Dashboard. Tacoma Park, MD: The Democracy Collaborative.

Dubb, S., McKinley, S., \& Howard, T. (2013). Achieving the anchor promise: Improving outcomes for low-income children, families, and communities. Takoma Park, MD: The Democracy Collaborative at the University of Maryland.

Guinan, J., McKinley, S., \& Yi, B. (2013). Raising student voices: Student action for University community investment. College Park, MD. Responsible Endowments Coalition and the Democracy Collaborative.

Harkavy, I., \& Hartley, M. (2008). Pursuing Franklin's democratic vision for higher education. 
Peer Review, 10 (2/3), 13-17. Retrieved from https://www.aacu.org/publicationsresearch/periodicals/pursuing-franklins-democratic-vision-higher-education

Jacoby, B. (2009). Civic engagement in higher education. San Francisco, CA: Jossey-Bass.

Kebea, J.J. (2016). Engaging students in the anchor mission of the university: A mixed-methods study utilizing the Delphi method. Retrieved from ProQuest Dissertations \& Theses Global

Linstone, H. \& Turoff, M. (1975). The Delphi method: Techniques and applications. Reading, MA: Addison-Wesley Publishing Company.

Rayens, M.K. \& Hahn, E.J. (2000). Building consensus using the policy Delphi method. Policy, Politics, \& Nursing Practice, 1 (4), 308-315. https://doi.org/10.1177/152715440000100409

Renaud, J.P. (2008). Morrill Act. In Encyclopedia of the Social and Cultural Foundations of Education (p. 518). Thousand Oaks, CA: SAGE Publications.

Saltmarsh, J., Hartley, M., \& Clayton, P.H. (2009). Democratic engagement white paper. Boston, MA: New England Resource Center for Higher Education. Retrieved from https://repository.upenn.edu/cgi/viewcontent.cgi?article=1252\&context=gse_pubs

Saltmarsh, J., \& Driscoll, A. (2015). Carnegie selects colleges and universities for 2015 Community Engagement Classification. Retrieved from http://www.carnegiefoundation.org/newsroom/news-releases/carnegie-selects-collegesuniversities-2015-community-engagement-classification/

Skulmoski, G., Hartman, F., \& Krahn, J. (2007). The Delphi method for graduate research. Journal of Technology Education, 6 (1), 1-21. https://doi.org/10.28945/199

Sumison, T. (1998). The Delphi technique: An adaptive research tool. British Journal of Occupational Therapy, 61 (4), 153-156. https://doi.org/10.1177/030802269806100403

Von der Gracht, H.A. (2012). Consensus measurements in Delphi studies. Review and impactions for future quality assurance. Technological Forecasting and Social Change, 79 (8), 1525-1536. https://doi.org/10.1016/j.techfore.2012.04.013

Wittman, A., \& Crews, T. (2012). Engaged learning economies: Aligning civic engagement and economic development in community-campus partnerships. Boston, MA: Campus Compact. 


\section{Author Information}

Jennifer Johnson Kebea

Lindy Center for Civic Engagement

Drexel University

3210 Cherry Street

Philadelphia, PA 19104

Email:jpj38@drexel.edu

Telephone: 215.895.2097

Twitter: @JenJohnsonKebea

LinkedIn: www.linkedin.com/in/jenniferkebea/

Dr. Jennifer Johnson Kebea is the executive director of the Lindy Center for Civic Engagement at Drexel University in Philadelphia, PA. With over a decade of experience in higher education, Dr. Kebea has been part of Drexel University's expanding efforts around civic engagement since 2009. Her research interests exist at the intersection of universities' dual roles to serve as both civic educators of students and as anchor institutions within their surrounding communities. 